American Journal of Agricultural and Biological Sciences 3 (1): 321-324, 2008

ISSN 1557-4989

(C) 2008 Science Publications

\title{
The Effect of Adding Zeolite to Soils in Order to Improve the N-K Nutrition of Olive Trees. Preliminary Results
}

\author{
R. Perez-Caballero, J. Gil, C. Benitez and J. L. Gonzalez \\ Departamento de Quimica Agricola y Edafologia, Universidad de Cordoba, Campus de Rabanales, \\ Edificio Marie Curie, Crta N-IVa, km 396, 14014 Cordoba, Spain
}

\begin{abstract}
This paper describes an experiment performed in order to study the possibility of using zeolite in organic olive groves. Soil and leaf analysis was performed and an increase in soil N levels was observed. Furthermore, higher levels of $\mathrm{K}$ in the soil and the trees point to the improved nutritional potential of these soils in terms of $\mathrm{K}$, as a result of adding zeolite. The results obtained under experimental conditions can be extrapolated for real plantations in the area and will also lead to significant water savings, greater efficiency, decreased use of fertilizers and less contamination of underground water supplies, which can then be used elsewhere.
\end{abstract}

Keywords: zeolite, olive trees, levels of $\mathrm{N}$ and $\mathrm{K}$

\section{INTRODUCTION}

Zeolites are a group of minerals, highly crystalline hydrated aluminosilicates that, when dehydrated, develop a porous structure with minimum pore diameters of between 3 to $10 \AA$. The structural frame is made up of $\mathrm{Si}-\mathrm{O}\left(\mathrm{SiO}_{4}{ }^{4-}\right)$ and $\mathrm{Al}-\mathrm{O}\left(\mathrm{AlO}_{4}{ }^{5-}\right)$ tetrahedrons, which bond together sharing vertices and forming square and hexagonal structures.

All zeolites are considered molecular sieves, materials that can selectively absorb molecules based on their size. Zeolites are one of the greatest cationic interchangers and their (E.C) cationic interchange capacity is two to three times greater than other types of minerals found in soils ${ }^{[1]}$.

The application of zeolites to soils increases their E.C, and as a result, it increases nutrient retention capacity. Furthermore, the addition of zeolites usually increases $\mathrm{pH}$ levels $\mathrm{s}^{[1]}$.

HuANG and PETROvic ${ }^{[2]}$ examined the possible advantages of applying zeolites to soils; they proposed the application of these minerals in order to reduce the leaching of nitrates in golf courses located on sandy soils. RODRíGUEZ et al ${ }^{[3]}$ confirmed that zeolite mixed with manure increases the effectiveness of organic fertilizers on meadowland soils.

Subsequently, it was demonstrated that zeolite is an important resource in agriculture, owing to its water and ammonium retention capacity ${ }^{[4]}$ and because it helps to reduce nitrogen loss ${ }^{[5]}$. Furthermore, it has been verified that, when mixed with nitrogen, phosphorous and potassium compounds, zeolite enhances the action of such compounds as slow release fertilizers, both in horticultural and extensive crops ${ }^{[6,7]}$. Hence, zeolite acts as a slow release fertilizer, giving the plant access to water and nutrients for longer, which results in a significant saving in water resources and reducing the amount of fertilizer to be applied ${ }^{[8]}$, thus helping to decrease the amount of water used per crop and the contamination of aquifers resulting from the overuse of fertilizers.

\section{MATERIAL AND METHODS}

The experiment was performed on an area of land located in the district of Antequera (Malaga, Spain). This area of land is populated with adult trees (olive, hojiblanca variety) with 2 or 3 feet between them and farmed in accordance with organic methods. The zeolite used (zeomin) was mainly made up of philipsite, with analcime, magnesium calcite and calcium albite (X-ray diffraction), with a water retention capacity of $35 \%$ $(\mathrm{p} / \mathrm{p})$ (determined using a tensiometer) and a cationic interchange capacity of approximately $80 \mathrm{cmol}_{(+)} / \mathrm{kg}^{[9]}$. The experiment was carried out on a "calcareous cambisol" soil ${ }^{[10]}$.

The zeolite was applied to randomly selected $12 \mathrm{x}$ $12 \mathrm{~m}$ plots of land. It was applied in triplicate at the beginning of the experiment in doses of $0,0.5,1,2,3$ and $4 \mathrm{~kg} / \mathrm{m}^{2}$.

Soil samples were collected from all the plots of land in February and July 2003 and January 2004. Kjeldahl nitrogen ${ }^{[11]}$ was determined in triplicate, and potassium was extracted using $1 \mathrm{~N}$ ammoniumacetate $^{[12]}$. 
Leaf samples were collected on the same dates as the soil samples; nitrogen levels ${ }^{[11]}$ were determined in triplicate in fresh matter, and following the mineralization of the sample, the potassium levels were determined ${ }^{[13]}$ using atomic emission.

Furthermore, oil yield and acidity analyses were performed on the olives during the campaign ${ }^{[12]}$.

Finally, an analysis of variance was carried out following Tukey's comparison procedure $(p<0.05)$, considering the different parameters studied as variables and the sampling dates and doses of fertilizers used as sources of variation ${ }^{[14]}$.

The year prior to the experiment (October 2003), cow manure was applied. Under no circumstances were conventional fertilizers added and the phytosanitary treatments used were permitted in accordance with legislation governing organic crops.

\section{RESULTS AND DISCUSSION}

Figure 1 shows the significant increase observed in the nitrogen levels of soils where higher doses of zeomin had been applied (Fig. 1.a). From doses of 3 $\mathrm{kg} / \mathrm{m}^{2}$ upwards, significant differences in the levels of $\mathrm{N}$ in the soil were observed. In relation to the sampling date, significantly higher values were observed for soils in the winter period.

In relation to leaf levels of $\mathrm{N}$ (Fig. 1.b), although the application of zeolite does not give rise to significant differences, the sampling dates revealed significantly higher values in summer following the trees' period of increased biological activity.

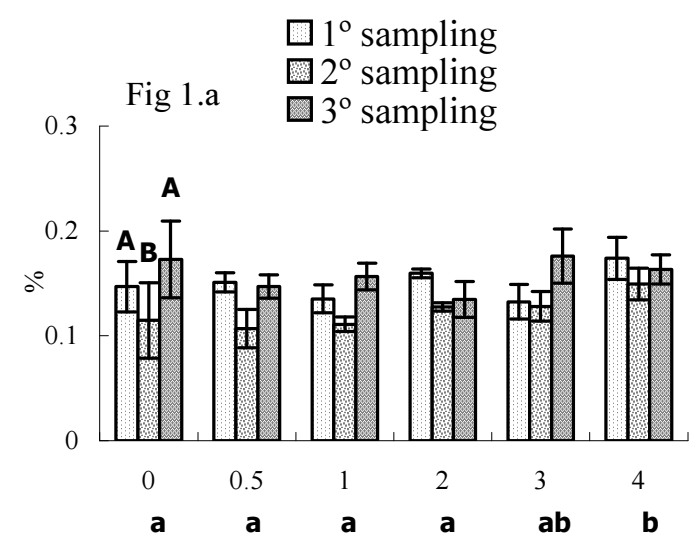

Dose $\left(\mathrm{kg} / \mathrm{m}^{2}\right)$

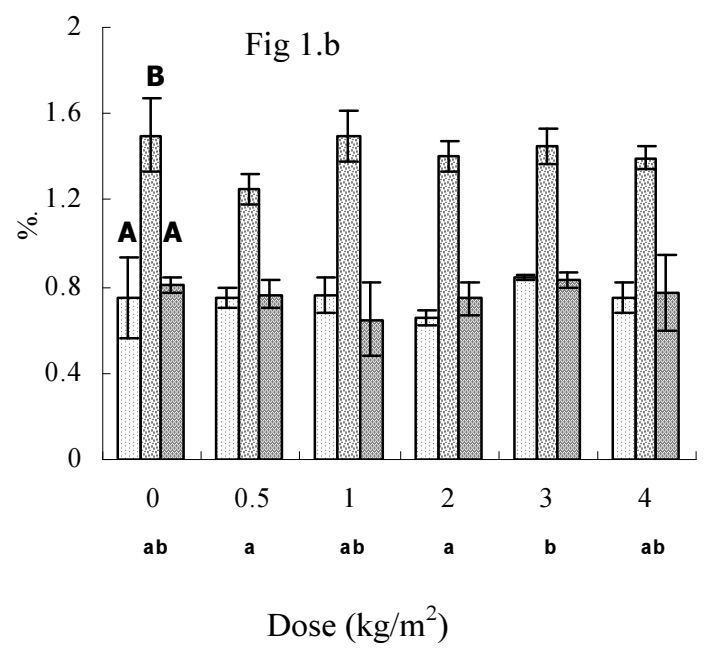

Fig.1: Evolution of the contents of $\mathrm{N}$ in soil (1.a) and leaf (d.m) (1.b). *Different letters indicate significant differences at $95 \%$ C.I. $(\mathrm{p}<0.05)$

As regards levels of potassium in the soil (Fig. 2.a), a significant increase was observed with higher doses of zeomin., The highest levels of $\mathrm{K}$ in the soil were observed for doses of 3 and $4 \mathrm{~kg} / \mathrm{m}^{2}$. Furthermore, the sampling date also indicated a significant increase in the levels of potassium in the soil.

Leaf levels of K (Fig. 2.b) were clearly affected by the addition of zeolite, although there were no significant differences according to the dose used. The sampling date also significantly affected leaf levels of K.

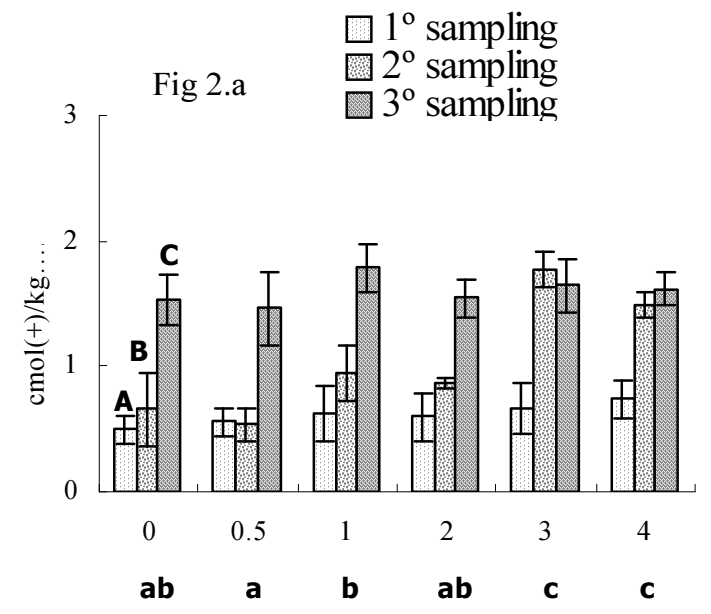

Dose $\left(\mathrm{kg} / \mathrm{m}^{2}\right)$ 


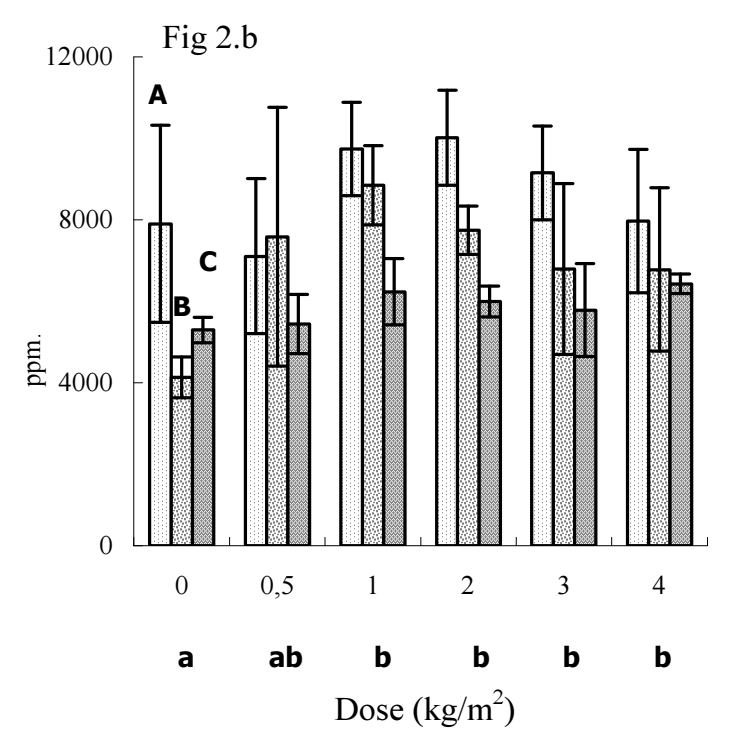

Fig. 2: Evolution of the contents of $\mathrm{K}$ in soil (2.a) and leaf (d.m) (2.b) *Different letters indicate significant differences at $95 \%$ C.I. $(\mathrm{p}<0.05)$

Table 1 shows the different harvest parameters: tree weight, oil yield and acidity level of the oil. There were no significant differences in these parameters in this first campaign studied.

Table 1: Analysis of the yield and acidity of the obtained olive

\begin{tabular}{cccc}
\hline $\begin{array}{c}\text { Dose } \\
\text { zeolite }\end{array}$ & $\begin{array}{c}\text { Weight } \\
\text { fruits/tree }(\mathrm{kg})\end{array}$ & $\begin{array}{c}\text { Greasy } \\
\text { yield }(\%)\end{array}$ & $\begin{array}{c}\text { Acidity } \\
\left({ }^{\mathrm{o}}\right)\end{array}$ \\
\hline 0 & $28^{\mathrm{a}}$ & $24.2^{\mathrm{ab}}$ & $0.4^{\mathrm{a}}$ \\
0.5 & $34.9^{\mathrm{a}}$ & $25.5^{\mathrm{b}}$ & $0.5^{\mathrm{a}}$ \\
1 & $47.4^{\mathrm{a}}$ & $23.9^{\mathrm{ab}}$ & $0.4^{\mathrm{a}}$ \\
2 & $42.5^{\mathrm{a}}$ & $24.6^{\mathrm{ab}}$ & $0.5^{\mathrm{a}}$ \\
3 & $27.5^{\mathrm{a}}$ & $22.5^{\mathrm{a}}$ & $0.4^{\mathrm{a}}$ \\
4 & $35.2^{\mathrm{a}}$ & $24.1^{\mathrm{ab}}$ & $0.4^{\mathrm{a}}$ \\
\hline
\end{tabular}

Different letters in superscript in a row indicate significant differences $(\mathrm{p}<0.05)$.

Adding zeolites to soils has a much more patent effect on levels of residual $\mathrm{N}$, where doses of 3 and 4 $\mathrm{kg} / \mathrm{m}^{2}$ led to significant increases. This result is due to the absorption of $\mathrm{NH}_{4}^{+}$on zeolites and the reduced losses of $\mathrm{NO}_{3}{ }^{-}$through leaching ${ }^{[5]}$. This increase in $\mathrm{N}$ represents enrichment of between 3.0 and $8.5 \mathrm{~kg} / \mathrm{ha}$ in this first year for doses of 3 and $4 \mathrm{~kg} / \mathrm{m}^{2}$ respectively, which should affect subsequent years.

Furthermore, when there are higher leaf levels of $\mathrm{N}$, there are lower levels of residual $\mathrm{N}$, owing to the absorption of this nutrient by the plants in spring and early summer.

In relation to $\mathrm{K}$, the effect of adding zeolites is even more manifest than for $\mathrm{N}$, both in terms of leaf and residual levels. The greatest increases of $\mathrm{K}$ in the soil occur at doses of 3 and $4 \mathrm{~kg} / \mathrm{m}^{2}$, representing an increase of between 12 and $16 \mathrm{~kg}$ of $\mathrm{K}_{2} \mathrm{O} / \mathrm{ha}$ in the soil. This result concurs with the findings of KIRK and OTHMER $^{[15]}$. As with $\mathrm{N}$, these increases of $\mathrm{K}$ will have a positive effect on subsequent years.

During this first campaign, it should be pointed out that significant differences were not observed in the harvest parameters specified, although in tree crops, especially olive trees, the influence of fertilizers does not become apparent until the third or fourth year of application.

\section{REFERENCES}

1. Ming, D.W. and BoEtTinger, J.L. 2001. Zeolites in soil environments. p. 323-345. In: D.L. Bish and D.W. Ming (ed.) Natural Zeolites: Occurrence, Properties, Applications. Reviews in Mineralogy and Geochemistry, vol. 45. Mineralogical Society of America and Geochemical Society, Washington, DC.

2. Huang,Z.T.and Petrovic,A.M.1994. Clinoptilolite zeolite influence on nitrate leaching and nitrogen use efficiency in simulated sand based golf greens. J. Environ. Qual. 23 (6), 1190-1194.

3. Rodríguez, I.; Crespo, G.; Rodríguez, M. and AGUILAR,M.1994. Efecto de diferentes proporciones de excreta-zeolita en el rendimiento y composición química de pacinum maximum vc. Likoni. Re. Cubana. Cienc. Agric. 28, 113-117.

4. Notario, J.S.; ARTEAGa, I.J.; GonZalez, M.M. and GARCíA, J.E. 1994. Response of alfalfa to a phillipsite-based selow-release fertilizer. Commun. Soil Sci. Plant. Anal. 25 (13\&14), 2231-2245.

5. John, C.; Del Valle, G.; Marrero, V.; MuÑIz, O.; Beltrán, R.; Sotlongo, J.; Gil, R.; Delgado, N. and CHONG, D. 1998. Generalización del empleo de la zeolita, como aditivo de la urea en cultivos de importancia económica. In: Producción de cultivos en condiciones tropicales. I S D N 959-7111-04-7, pp 193-195.

6. DWAIRI, J. M. 1998a. Evaluation of Jordanian zeolite tuff as a controlled slow-released fertilizer for $\mathrm{NH}_{4}{ }^{+}$Environmental Geology. 34(1):1-4.

7. DWAIRI, J. M. 1998b. Renewable, controlled and environmentally safe phosphorous released in soil mixtures of $\mathrm{NH}_{4}^{+}$-phillipsite tuff and phosphate rock. Environmental Geology. 34 (4):293-296. 
8. Grande, J.A.; Carmona, P.; GonzÁlez, A. y De LA TORRE, M.L. 1995. Experiencia con zeolitas en cultivos de fresón. Análisis factorial de los datos de una parcela experimental en Lepe (Huelva). Avances en la Investigación en Zona No Saturada. pp 373-381. Sev. Pub. Gobierno Vasco. Vitoria.

9. Bower, C. A.; Reitemeier, R. F.; Fireman, M. 1952. Exchangeable cations analisis of saline anal alkali soils. Soil Science 73: 251.

10. FAO. 1996. Mapa digital de suelos del mundo y propiedades derivadas (CD-ROOM). FAO. Roma. Italia.

11. Duchaufour, Ph. 1975. Manual de Edafología. Ed. Toray Mansson, S.A. Barcelona. España.
12. M.A.P.A. 1994. Métodos oficiales de análisis. Ministerio de Agricultura, Pesca y Alimentación, 1. pp 221-285.

13. C. I. I. T. D. F. 1969. Métodos de referencia para la determinación de elementos minerales en vegetales. Anales de Edafología y Agrobiología. 28: 409-430.

14. STATISTICAL GRAPHICS CORPORATION 1994. Statgraphics. Plus, 3.1. Statistical Graphics System. Educational Institution Edition. USA.

15. KIRK, R. E. and OTHMER, D. F. 1991. Encyclopedia of Chemical Technology. $4^{\mathrm{a}}$ ed. John Wiley \& Sons, Inc., New York, 2240 pp. 